\title{
Everyday Social Support Processes: Household Members' Instrumental and Emotional Support of Entrepreneurs
}

\author{
Aviel Cogan (University of Strathclyde), \\ Tobias Pret (Illinois State University), \\ Melissa S. Cardon (University of Tennessee)
}

\begin{abstract}
While it is well-established that entrepreneurs benefit from social support, little is known about how and when instrumental and emotional support from household members facilitate entrepreneurial action and persistence. Through a longitudinal, qualitative study, we develop a conceptual framework that shows how social support from the household becomes an integral part of the everyday activities of entrepreneurs. In contrast to the perception of social support as static, our findings illustrate it as a dynamic, ongoing process which is core to business startup and growth over time. We also challenge the perspectives that households are simply repositories of resources and entrepreneurs passive recipients of support by demonstrating that social support is necessarily interactive, whereby entrepreneurs and households play a collaborative role in entrepreneurship. Finally, we join the debate concerning mechanisms of social support by suggesting that the main effect model and buffering hypothesis are not contradictory, but are instead interdependent.
\end{abstract}

Keywords: household, social support, emotion, process, artisan entrepreneurs

\section{Introduction}

Entrepreneurs rely on social support. As the process of starting and growing a business is resource intensive and emotionally demanding (Braun and Sieger, 2021; Cardon et al., 2012), entrepreneurs can greatly benefit from the social support (i.e. instrumental and emotional support) that network members provide (Kim et al., 2013; Nielsen and Klyver, 2020). Instrumental support is provided in various forms, such as financial, social and human capital (Brüderl and Preisendörfer, 1998; Edelman et al., 2016), and plays an influential role in the creation of new ventures, as it can increase entrepreneurs' business skills (Fielden and Hunt, 2011), productivity (Kuhn and Galloway, 2015) and success (Powell and Eddleston, 2013). Similarly, emotional support facilitates entrepreneurship by helping entrepreneurs cope with 
uncertainty (Arregle et al., 2015), persist in the start-up process (Klyver et al., 2018) and remain committed to their venture goals (Treffers et al., 2019). While research has traditionally focussed on the support provided by professional network members, such as peers, mentors and formal investors (Brush et al., 2001; Fielden and Hunt, 2011), an emerging body of literature highlights that household and family members are also invaluable sources of instrumental and emotional support for entrepreneurs (Arregle et al., 2015; Edelman et al., 2016).

Despite such recent advances, there remain a number of gaps in understanding of ongoing social support processes. In particular, studies into social support from household and family members are temporally limited and rarely explore the post-start-up period. Given that entrepreneurship is an open-ended process (Packard, 2017) which often requires the continuing involvement of entrepreneurs in everyday, hands-on activities (Johannisson, 2011), it may be assumed that their need for support continues over time. Since entrepreneurs have been shown to adapt their practices as they grow their businesses (Greenman, 2012; Jack et al., 2008), their support requirements may also change post-start-up. As such, there is a need to explore how social support processes evolve over time. Furthermore, while research has shed much needed light on the impact of social support on entrepreneurs, most studies adopt a rather deterministic approach and largely overlook the interactive dynamics and agency involved in social support processes (Chen and Klyver, 2021). Indeed, whereas outcomes of social support, such as entrepreneurial action (Arregle et al., 2015; Edelman et al., 2016) and persistence (Kim et al., 2013; Klyver et al., 2018), have been recognised, little is known about the multi-faceted and active roles that support providers, such as household members, play in facilitating the abilities of entrepreneurs to develop their businesses.

To advance understanding, we explore the research question: how and when does instrumental and emotional support from household members facilitate entrepreneurial action and persistence? We address this question through a longitudinal, phenomenological study of 10 artisan entrepreneurs and their household members. We selected this context to investigate ongoing social support processes asartisan entrepreneurs are known to engage with their households (Pret, 2017) and continue performing entrepreneurial activities post-start-up (Pret and Cogan, 2019).

Based on the experiences of participants, we develop a conceptual framework which illustrates how and when social support from the household becomes an integral part of everyday entrepreneurial activity. Our findings and model offer three main theoretical contributions to the social support and entrepreneurship literatures. First, in contrast to the 
perception of social support as static, we illustrate it as a dynamic, ongoing process which is core to the abilities of entrepreneurs to pursue venture start-up and growth over time. Second, we challenge the perspective that households are simply repositories of resources and entrepreneurs passive recipients of support by demonstrating that social support is necessarily interactive, whereby entrepreneurs and households play an active, collaborative role in entrepreneurship on an everyday basis. Third, we extend the main effect and buffering models of social support by suggesting that ongoing and problem-oriented mechanisms, which are often considered contradictory, are actually interdependent and that, within the high-stress context of entrepreneurship, problem-oriented stress-buffering becomes an ongoing main effect of social support. In addition to our theoretical contributions, we offer new insights into artisan entrepreneurship by demonstrating that its collaborative norms extend beyond the craft community into the household context and that emotions are not only a driving force in the creation of artisan ventures, but also a cyclical outcome of and influence on artisan activities over time.

\section{Research on Households and Social Support}

\section{Household context}

The impact of family on entrepreneurship has long been recognised (Aldrich and Cliff, 2003) and households in particular are perceived as influencing entrepreneurs (Alsos et al., 2014). However, research largely views businesses and households as separate spheres (Jennings and McDougald, 2007) and, as a result, the influence that households have on entrepreneurs remains 'woefully under-researched' (Carter et al., 2017: 128). Since understanding of what constitutes households and families varies significantly, explicit definitions are required. We consider all individuals related by birth, adoption or marriage to be family, whereas a household is a group of people "who may or may not be related living, or staying temporarily at the same address, with common housekeeping' (Wheelock and Oughton, 1996: 149). Thus, households are permeable, can include non-kin and are a product of the shared histories and cultures of their members (Ruef, 2020).

Within entrepreneurship research, households are mainly considered sources of data for exploring and measuring the activities of individual entrepreneurs (Kimmitt et al., 2020) or perceived as a fixed pool of resources (Bird and Wennberg, 2016; Gras and Nason, 2015). Only recently has research moved beyond understanding households as a separate part of the entrepreneur's life that is to be exploited, negotiated or accommodated (Carter et al., 2017), 
and begun to highlight that there are synergies between households and entrepreneurship (Eddleston and Powell, 2012). Specifically, there is a growing recognition that household and family members are crucial sources of social support for entrepreneurs (Arregle et al., 2015; Edelman et al., 2016).

\section{Social support theory}

Developed within the health sciences to explain why people who receive mental and physical support are in better health than others (Cassel, 1976; Cobb, 1976), the concept of social support refers to "the social resources that persons perceive to be available or that are actually provided to them by nonprofessionals in the context of both formal support groups and informal helping relationships' (Cohen et al., 2000: 4). Research usually divides this multidimensional construct into (1) instrumental and (2) emotional support (Adams et al., 1996; Suurmeijer et al., 1995) and explores the (3) mechanisms through which it benefits individuals (House et al., 1988; Thoits, 2011) as well as its (4) outcomes (Bavik et al., 2020). We discuss each of these below.

\section{Instrumental support}

Within the wider social support literature, instrumental support has received comparatively limited attention and, when it is recognised, it often remains vague and lacks critical engagement (Barrera, 1986; LaRocco et al., 1980). As a result, definitions used by most entrepreneurship studies are also somewhat broad, commonly describing instrumental support as 'tangible assistance aimed at solving problems' (Klyver et al., 2018: 710). Following Brüderl and Preisendörfer (1998) and Edelman et al. (2016), we therefore draw on the concept of capital to explore how and when distinct forms of instrumental support are provided to and utilised by entrepreneurs. Specifically, we employ the concept of household capital, which differentiates between the financial, social, human (Rodriguez et al., 2009; Steier, 2009) and symbolic capital (Bourdieu, 1977) that household members provide entrepreneurs.

First, household financial capital is conceived as monetary assets (i.e. household income) and other tangible assets (Carter, 2011). It is often provided without expectation of repayment (Edelman et al., 2016) and can grant funding which entrepreneurs may not otherwise be able to secure externally (Danes et al., 2009). Thus, the provision of financial capital has been perceived as the most significant form of support (Braun and Sieger, 2021). Second, household social capital refers to the household's 'networks of relationships in which personal and organizational contacts are closely embedded' (Edelman et al., 2016: 431) and 
which grant entrepreneurs connections that may otherwise be unavailable or difficult to develop (Kotha and George, 2012). Third, household human capital has been interpreted as the combined abilities, skills and values of cohabitants ${ }^{1}$ (Caputo and Dolinsky, 1998), access to which has been shown to support start-up activities (Bird and Wennberg, 2016). Finally, symbolic capital is associated with the possession of status and reputation (Bourdieu, 1977) and is objectified in awards and recognitions (Pret, 2021). While it has been shown that this form of capital is particularly powerful (Pret et al., 2016), little is known about the impact of household members on its development.

Since most entrepreneurship studies that investigate the use of household resources examine only one or two forms of capital (Bird and Wennberg, 2016; Caputo and Dolinsky, 1998), there is much to be learned about how and when multiple forms of household capital can support entrepreneurial actions. Furthermore, research on household capital and instrumental support both suffer from a dearth of process studies, taking for granted that households and other support systems make this tangible assistance available without investigating how and when such activities unfold and how household members and entrepreneurs actively engage in this process.

\section{Emotional support}

Emotional support has been of primary interest within the wider social support literature (Adams et al., 1996; Thoits, 2011). According to Taylor (2011: 190), 'emotional support involves providing warmth and nurturance to another individual and reassuring ... that he or she is a valuable person for whom others care'. Interestingly, research shows that the belief in the availability of emotional support (perceived support) can have a stronger impact on mental health than its actual enactment (received support), as knowledge of its existence can sufficiently enhance an individual's ability to cope with stress (Barrera, 1986; Thoits, 1995).

Within the entrepreneurship literature, emotional support has been described as 'listening and providing empathy' (Klyver et al., 2018: 710) and 'encouragement, understanding, attention, and positive regard' (Powell and Eddleston, 2017: 265). Klyver et al. (2020) propose that emotional support can help entrepreneurs solve problems, cope with uncertainty and persist during challenging periods by promoting optimism, passion and creativity. Furthermore, emotional stability allows entrepreneurs to focus their efforts on

\footnotetext{
1 We embrace the British terminology and define a cohabitant as 'someone who lives in the same house, apartment, etc. as someone else' (McIntosh, 2013: 311). While in American English the term is sometimes used to denote a romantic relationship between household members, we do not assume this.
} 
growing their ventures (Brüderl and Preisendörfer, 1998). However, while an emerging body of research explores the impact of emotions on entrepreneurs (Cardon et al., 2012), there is a 'preponderance of studies addressing intra rather than interpersonal questions' (Jennings et al., 2015: 114). Thus, research into interactive emotional support processes can make valuable contributions to knowledge.

Although the emotional support that household members provide to entrepreneurs is often acknowledged (Alsos et al., 2014; Danes et al., 2009), little is known about this process and empirical investigations outside of family-owned firms are rare (Arregle et al., 2015). Even studies that adopt a social support perspective to explore the impact of household and family members on entrepreneurs usually pay only limited attention to how emotional support is provided (Edelman et al., 2016; Powell and Eddleston, 2013). Since entrepreneurial firms are often owned and run by solo entrepreneurs who are unable to exchange empathy and encouragement with co-workers (Powell and Eddleston, 2017), this lack of knowledge seriously impedes understanding of entrepreneurial processes.

With regard to its temporal relevance, studies have shown that emotional support is most helpful for entrepreneurs during the nascent venture stage (Brüderl and Preisendörfer, 1998), as it increases the likelihood that entrepreneurs will successfully transition to selfemployment (Klyver et al., 2018). However, during subsequent business development, it has been shown that emotional support can 'become useless or even act as a break' (Arregle et al., 2015: 333) once entrepreneurs learn how to deal with challenges by themselves. As such, Klyver et al. (2018: 714) argue that younger entrepreneurs are more likely to require such support, as they are 'less experienced at regulating emotions' than older, more seasoned entrepreneurs. Although the insights from these few studies are valuable, there remains a paucity of research on the ongoing emotional needs of entrepreneurs.

\section{Support mechanisms}

While the significance of social support to health and work outcomes is well established (House et al., 1988; Bavik et al., 2020), a primary debate within the literature regards the mechanisms through which social support produces its positive impacts (Taylor, 2011): namely, whether social support has a direct effect on well-being (the main effect model) or acts as a moderator of stress (the buffering hypothesis) (Cohen and Wills, 1985).

In the main effect model, social support is perceived as the generalised benefits of social integration (LaRocco et al., 1980), where close ties to social others help individuals attain a sense of stability, belonging and esteem, and avoid the negative effects of social isolation 
(Thoits, 1982). Thus, this model proposes that social support is always beneficial, regardless of any particular circumstances in an individual's life (Broadhead et al., 1983). It is preventative, rather than ameliorative and works on an ongoing basis (Thoits, 2011).

In contrast, the buffering hypothesis proposes that 'social support facilitates coping with crisis and adaptation to change ... it is in moderating the effects of the major transitions in life and of the unexpected crises that the effects should be found' (Cobb, 1976: 302). It therefore positions social support as a negativity buffer (Cassel, 1976; Cohen and Wills, 1985) which helps individuals evaluate stressful situations more positively and provides them with resources necessary to cope with and overcome problems when they arise (LaRocco et al., 1980). In the buffering hypothesis, social support is reactive, rather than proactive (Kaplan et al., 1977).

After decades of study, evidence for and challenges to both models have emerged (Taylor, 2011; Thoits, 2011). Since neither its direct nor stress moderating effects alone are able to fully explain how social support operates (Bavik et al., 2020; Cohen and Wills, 1985), there is a need for research to consider how the two mechanisms are intertwined within more complex processes. However, studies continue to view these mechanisms as dichotomous, either measuring the degree of social integration and treating social support as a static structural resource (Goodwin et al., 2004; House et al., 1988), or adopting a purely 'problem-oriented' approach and focussing on its utility in times of crisis (Bavik et al., 2020). Both approaches neglect the 'everyday' occurrences of social support (Suurmeijer et al., 1995), viewing it either as something that exists or not, or as simply a solution to a time-bound problem. Furthermore, this deterministic perception of social support largely overlooks the interactive dynamics and agency involved in this process (Chen and Klyver, 2021; Nielsen and Klyver, 2020). After all, social support is not merely 'a commodity that resides in the provider and passes to the recipient' (Gottlieb and Bergen, 2010: 512), but requires interpersonal activities performed by both. Bridging the main effect and buffering models and conceptualising social support as an interactive process may thus allow for a more nuanced understanding of how and when social support benefits individuals over time.

\section{Support outcomes: entrepreneurial action and persistence}

There is a long tradition within the health sciences of demonstrating the positive outcomes of social support, such as protection against psychological distress, contributions to physical health and reduction in mortality (Bavik et al., 2020; Taylor, 2011). Within the entrepreneurship literature, commonly featured outcomes of social support are entrepreneurial action (Arregle 
et al., 2015; Edelman et al., 2016) and persistence (Kim et al., 2013; Klyver et al., 2018), both of which must be considered and defined.

Following the seminal works of Kirzner (1973) and Schumpeter (1942), most entrepreneurship scholars adhere to the notion that entrepreneurial action encompasses startup activities involved in new venture creation, such as completing a business plan, seeking external funding and looking for potential partners (Edelman et al., 2016). Accordingly, they view entrepreneurial action as culminating with the venture 'becoming an operational economic entity with sustained presence in the marketplace' (Davidsson and Gruenhagen, 2021: 1102). Others, however, argue that entrepreneurship involves 'open-ended processes, [and] ongoing journeys that have no definitive end' (Packard, 2017: 543). From this perspective, entrepreneurial actions are not limited to the founding of businesses, but rather represent an ongoing 'type of organizational activity that involves creative action, innovative exchanges and deal-making' (Greenman 2012: 116). Following this approach, we define entrepreneurial action as judgmental decision making about the employment of resources in pursuit of founding and growing a venture (Foss and Klein, 2010). This conceptualisation encompasses start-up activities, described above, as well as everyday entrepreneurial activities undertaken to grow ventures, such as 'diversifying by developing new products and services, [dealing with] cash flow problems ... and the search for personal and organizational reputation' (Greenman, 2013: 636). This perception facilitates investigations of how the long, 'messy' journey of entrepreneurship unfolds over time (Welter et al., 2017).

Our understanding of entrepreneurial action speaks to the significance of entrepreneurial persistence. Defined as 'continu[ing] with an entrepreneurial opportunity ... in the face of opposing motivational forces' (Holland and Shepherd, 2013: 333), entrepreneurial persistence becomes especially important when entrepreneurship is perceived as an open-ended journey, rather than a time-bound, goal-focused task. The ability to sustain entrepreneurial activities over time has been shown to be more integral to success than rapid growth (Kim et al., 2013), indicating that entrepreneurial persistence is a core facilitator of entrepreneurial action (Cardon and Kirk, 2015). Thus, the notion that entrepreneurial persistence is an ongoing feat, which also exists in relation to overcoming problems, positions it as an opportune construct through which to study social support as a process (Klyver et al., 2018).

\section{Methods}

This study adopts a qualitative approach, which is appropriate when addressing research questions of 'how' and 'why', rather than measuring 'how many' (McKeever et al., 2015). In 
answer to calls for more methodological and paradigmatic diversity in entrepreneurship research (Shepherd, 2015), we embrace an interpretivist perspective and conduct an interpretative phenomenological analysis (Cope, 2011; Smith et al., 2009). A growing number of studies adopt phenomenological approaches (Pret and Carter, 2017; Pret et al., 2016; Shaw et al., 2017), because they are well-suited for 'developing both new theoretical constructs and enhancing the potency of existing ones, bridging the gap between real-life occurrences and theoretical concepts' (Cope, 2011: 610). Phenomenological research explores the lived experiences of participants through their subjective interpretations to gain comprehensive knowledge of their personal and social worlds (Berglund, 2007). While phenomenological research approaches and small sample sizes constrain generalisation of results to wider populations (Cope, 2005), they enable investigations of social phenomena that are rich in detail and require 'thick description' (McKeever et al., 2015: 54). In this study, we aim to understand how social support processes unfold temporally and agentially. As such, we chose this method for its utility in addressing questions of process, content and dynamics (Lewis, 2021) and discovering the meanings behind actions (Berglund, 2007).

\section{Context and participant selection}

In order to gain a deeper understanding of the ongoing process of social support from the household, we needed to study entrepreneurs who continue performing the daily work of entrepreneurship post-start-up and who are known to engage with their households. We thus decided to investigate the experiences of artisan entrepreneurs. As Welter et al. (2017) argue, exploring the lives of 'everyday entrepreneurs', such as artisans, facilitates examinations of ongoing entrepreneurial processes. Whereas research usually focusses on entrepreneurs who seek to establish high-growth businesses from which they can relinquish daily operations (Sarasvathy, 2021), such a sample would have inhibited our ability to study continuing social support needs and processes. Furthermore, there is a need to account for the experiences of those who establish small, slow-growth enterprises and maintain hands-on engagement (Welter et al., 2017). Such entrepreneurs are likely to draw on social support for longer and in different ways than those who seek to sell or turn over management of their firms. As Pret and Cogan (2019) highlight, the development of artisan businesses requires a high degree of continued manual input from entrepreneurs: as artisans, they are their businesses. Furthermore, the vast majority of artisan entrepreneurs are sole proprietors (Burns et al., 2012), who lack team members with whom they can share their experiences (Swab et al., 2021). Artisan 
entrepreneurship thus appears a particularly appropriate context to study the process of household instrumental and emotional support.

We first advertised our proposed study to artisans in the UK through specialised business networks. While our call for participants generated considerable interest, heeding the advice of Smith et al. (2009), we selected only 10 entrepreneurs using purposeful sampling to cover a breadth of experiences (e.g. different crafts, age groups and years of business operation; see Table 1). ${ }^{2}$ During initial conversations, it quickly became apparent that their stories would add interesting perspectives to our work. Supplemental Appendix 1 (online) features vignettes that provide further narrative detail about participating entrepreneurs and their households. In line with our understanding that entrepreneurship is an open-ended process and that entrepreneurs in slow-growth industries (like crafts) may continue to grow their businesses over extended periods of time (Sarasvathy, 2021), we deliberately included participants who owned their studios for multiple years, as well as those who recently started up. All participants share their households with partners or spouses, except for Frank, who has been close friends with his cohabitant, Felix, since childhood. Furthermore, we selected sole proprietors whose household members have their own, separate careers. This allowed us to investigate the role that households play outside of the family business context.

Table 1. Overview of Research Participants

\begin{tabular}{ccccccc}
\hline Name & Age & Craft & $\begin{array}{c}\text { Studio } \\
\text { Owner For }\end{array}$ & Children & $\begin{array}{c}\text { Household } \\
\text { Member }\end{array}$ & $\begin{array}{c}\text { Cohabitants } \\
\text { For }\end{array}$ \\
\hline Amy & 29 & Accessory making & 1 year & 0 & Adam* (Partner) & 7 years \\
Betty & 32 & Book making & $<1$ month & 0 & Brenda (Partner) & $<1$ year \\
Carol & 36 & Yarn dying & 6 years & 0 & Clara (Partner) & 12 years \\
Diana & 39 & Silversmithing & 9 years & 0 & Daniel* (Partner) & 10 years \\
Emily & 44 & Hand stitching & 6 years & 1 & Evan* (Spouse) & 23 years \\
Frank* & 46 & Pottery making & $<1$ month & 0 & Felix* (Friend) & $<1$ year \\
George* & 50 & Basket weaving & 9 years & 2 & Grace (Spouse) & 27 years \\
Holly & 52 & Teddy bear making & 3 months & 2 & Henry* (Partner) & 25 years \\
Isabel & 63 & Souvenir making & 3 years & 1 & Isaac* (Spouse) & 38 years \\
Julie & 64 & Printmaking & 3 years & 2 & Jack* (Spouse) & 29 years \\
\hline
\end{tabular}

Notes: *Denotes male entrepreneurs and household members.

Displayed information refers to the situations of participants at the start of the data collection.

\footnotetext{
${ }^{2}$ Notably, the sample consists of two men and eight women entrepreneurs. As is typical for phenomenological research, participants were chosen irrespective of their sex (cf. Cope, 2011; McKeever et al., 2015). However, this distribution is inadvertently reflective of the craft industry in the UK, where about 70\% of makers are women (Burns et al., 2012).
} 


\section{Data collection}

Our study adopts a longitudinal design, which is under-represented in entrepreneurship research, despite its capacity to generate valuable knowledge of entrepreneurial processes (cf. Cogan and Pret, 2020; Jack et al., 2008). Data collection was conducted primarily through five rounds of interviews: four with the entrepreneurs and one with the household members listed by name in Table 1 . Interviews with participating entrepreneurs were carried out in intervals of approximately 6 months and were conducted in the workshops or homes of participants, using everyday language.

Initial interviews were unstructured and began with open-ended questions, such as 'Tell me about your background' and 'Tell me about your business' to gain deep insights into the perspectives of participants (Cope, 2005). These initial discussions indicated that both instrumental and emotional support from the household play important roles in the everyday practices of artisan entrepreneurs. Accordingly, we adopted a semi-structured format in subsequent interviews to explore emerging themes. When these interviews suggested that household members were more instrumental than we previously appreciated, we decided to interview them, as well, in order to gain a more comprehensive understanding of the dynamics of participating households. Household members were interviewed via Skype or telephone, also using a semi-structured interview format. As shown in Supplemental Appendix 2 (online), interviews with participants lasted an average of 1.5 hours each and provided substantial quantities of rich empirical data (the 50 resulting interviews yielded over 1,200 single-spaced pages of transcript).

Furthermore, participant observations were conducted and documentary sources of information were accessed (e.g. the websites and social media profiles of participants) to fill potential gaps in understanding (McKeever et al., 2015). Specifically, following the in-person interviews, we stayed to observe the entrepreneurs for the remainder of the day to gain deeper knowledge of their everyday practices. In so doing, we were not only able to observe their creative actions, but also take notes regarding when they experienced difficulties and how they dealt with them (e.g. by calling home). We were able to witness their interactions with household members when they met for lunch or coffee and when we were invited to conduct follow-up interviews in their homes. In addition, we observed participants and their accompanying household members at craft fairs or exhibitions to explore their interactions with each other and members of their craft communities. 


\section{Data analysis}

Data collection and analysis occurred simultaneously. Following each interview, audio recordings were transcribed verbatim to enable systematic analysis of raw data. The data analysis adhered to the principles of interpretative phenomenological analysis, which sets forth a series of clear, accessible guidelines (Smith et al., 2009). Following Cope (2011), we performed the six steps described in Table 2 after each round of interviews.

Table 2. Data Analysis Process

\begin{tabular}{ll}
\hline Step & Description \\
\hline $\begin{array}{l}\text { 1. Familiarising } \\
\text { (Material reading) }\end{array}$ & $\begin{array}{l}\text { Interview transcripts, observation notes and other documents are read and } \\
\text { re-read to gain an appreciation for the participant's whole story and to recall } \\
\text { the interview(s) both cognitively and affectively (Pret et al., 2016). }\end{array}$ \\
$\begin{array}{l}\text { 2. Sense-making } \\
\text { (Note taking) }\end{array}$ & $\begin{array}{l}\text { Transcripts are annotated employing a 'free-textual analysis' technique } \\
\text { (Smith et al., 2009), which involves writing up notes to summarise, form } \\
\text { associations and develop preliminary interpretations. }\end{array}$ \\
$\begin{array}{l}\text { 3. Categorising } \\
\text { (Theme developing) }\end{array}$ & $\begin{array}{l}\text { Initial notes are used to develop emerging themes that appear salient to a } \\
\text { particular interview. This process is completed for each individual transcript, }\end{array}$ \\
$\begin{array}{l}\text { leading to a range of idiosyncratic coding schemes (Cope, 2011). } \\
\text { (Theme clustering) }\end{array}$ & $\begin{array}{l}\text { A meta-level analysis is conducted across interviews. Coding schemes are } \\
\text { compared between participants to search for links between their accounts, } \\
\text { identify patterns and develop superordinate concepts (Pret, 2017). }\end{array}$ \\
$\begin{array}{l}\text { 5. Interpreting } \\
\text { (Summary writing) }\end{array}$ & $\begin{array}{l}\text { Interpretive summaries are written up, consisting of narrative accounts of } \\
\text { each participant's experiences. They are shared with participants to gain their } \\
\text { feedback on the interpretations of the researchers (Shaw et al., 2017) }\end{array}$ \\
6. Explaining & $\begin{array}{l}\text { Emerging findings are compared to concepts in the literature. This abstraction } \\
\text { process involves moving iteratively between existing theory and the data to } \\
\text { gain a higher level of conceptualization (Pret and Carter, 2017). }\end{array}$ \\
\hline
\end{tabular}

We searched for emerging themes in the individual transcripts before comparing themes between participants and looking for patterns to develop superordinate categories (Smith et al., 2009). It became apparent during this process that, at the aggregate level, our findings regarding household support could be grouped into emotional and instrumental categories, the latter of which could be divided into founding and ongoing support. Emerging findings were then compared to arguments in the literature to gain a higher level of conceptualisation (Edmondson and McManus, 2007) and to identify how the data could contribute to current academic discussions of social support from the household. This led us to employ the concept of household capital to differentiate the various types of instrumental support that cohabitants provide entrepreneurs. Figure 1 displays the final data structure, including first-order codes, second-order themes and aggregate dimensions, which were developed through the analysis 
process. Furthermore, we present tables for each second-order theme in the findings section, which feature the first-order codes and examples of raw data.

Figure 1. Data Structure

First-Order Codes

- Financing start-up costs

- Equipping entrepreneurs with requisite tools

- Supplying raw materials

- Connecting entrepreneurs to craft organisations and suppliers

- Introducing customers to entrepreneurs and their businesses

- Performing core technical skills

- Influencing designs through providing creative insight

- Offering entrepreneurs business and customer relations advice

- Attending craft fairs as a family

- Explaining the legitimacy of entrepreneurs' crafts and businesses

- Promoting entrepreneurs' work and publicising them on social media

- Admiring the quality of entrepreneurs' crafted products

- Validating the creative abilities and business choices of entrepreneurs

- Expressing belief in entrepreneurs' future success

- Encouraging entrepreneurs to persevere in their business

- Inspiring entrepreneurs to reach their potential

- Persuading entrepreneurs to work through difficulties

- Protecting entrepreneurs against potential risks

- Sympathising with entrepreneurs about work issues

- Reassuring entrepreneurs that they are doing well
Second-Order Themes

Aggregate Dimensions

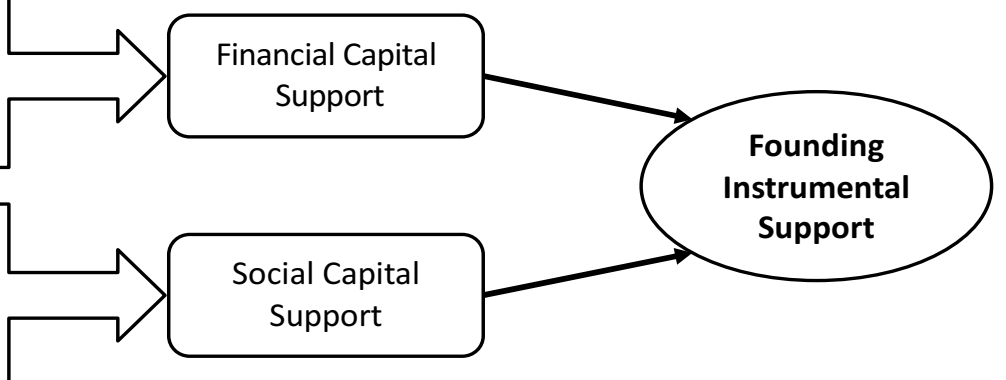

\section{Founding}

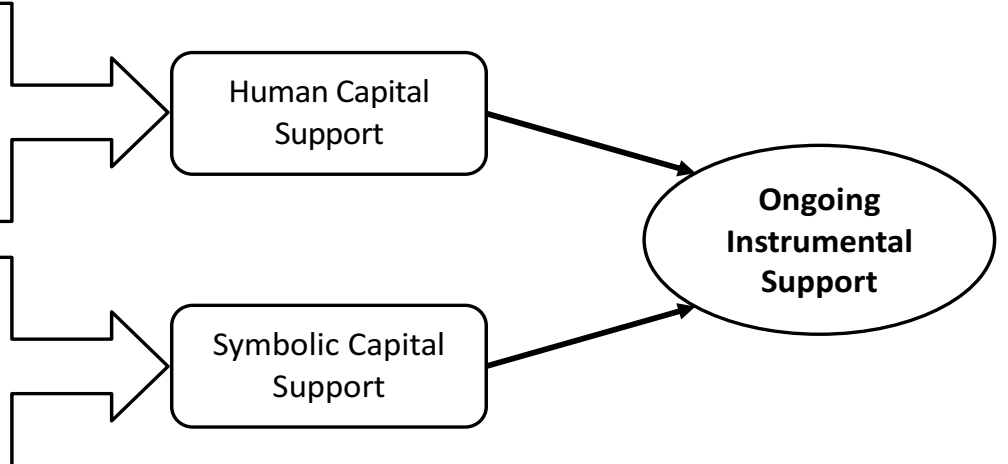

nstrumenta
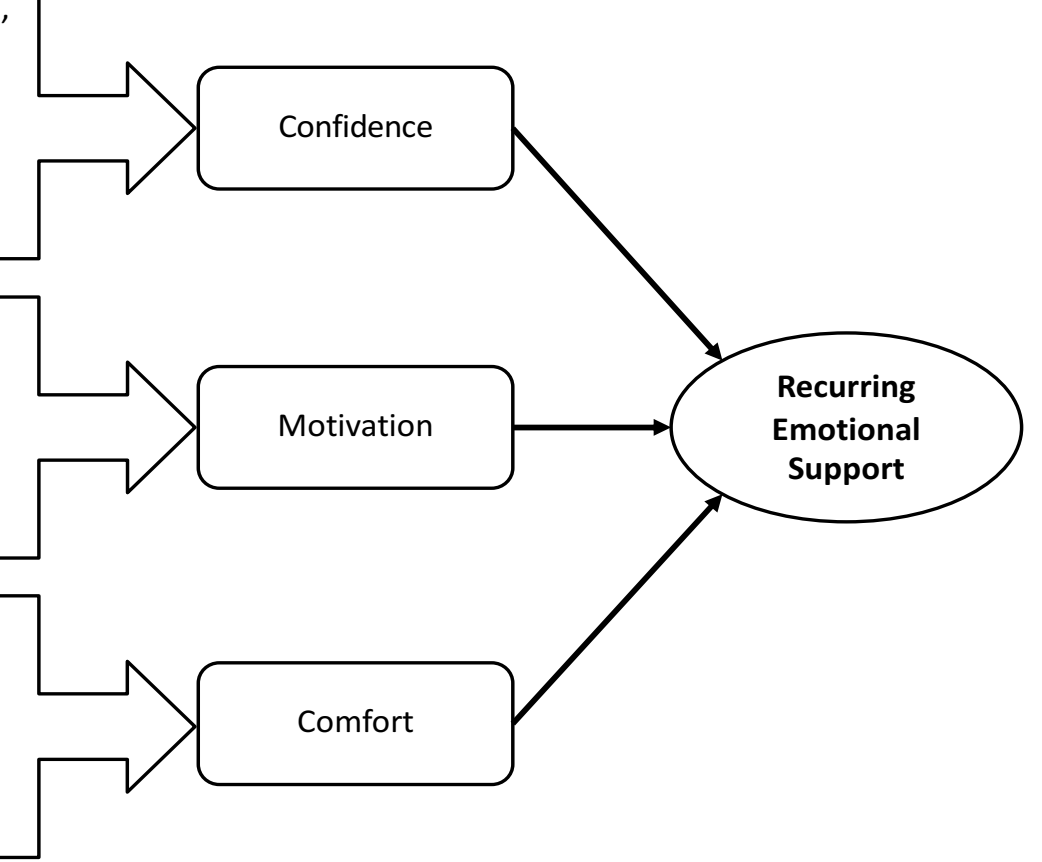


\section{Findings}

In this study, we seek to shed new light on social support processes and the interwoven relationship between business and household by investigating the research question: how and when does instrumental and emotional support from household members facilitate entrepreneurial action and persistence? Figure 2 represents the core findings of this study and illustrates the continuous, cyclical process of social support in which household members and entrepreneurs engage according to the founding and ongoing instrumental needs and recurring emotional states of entrepreneurs.

Figure 2. The Continuous, Cyclical Process of Social Support from the Household

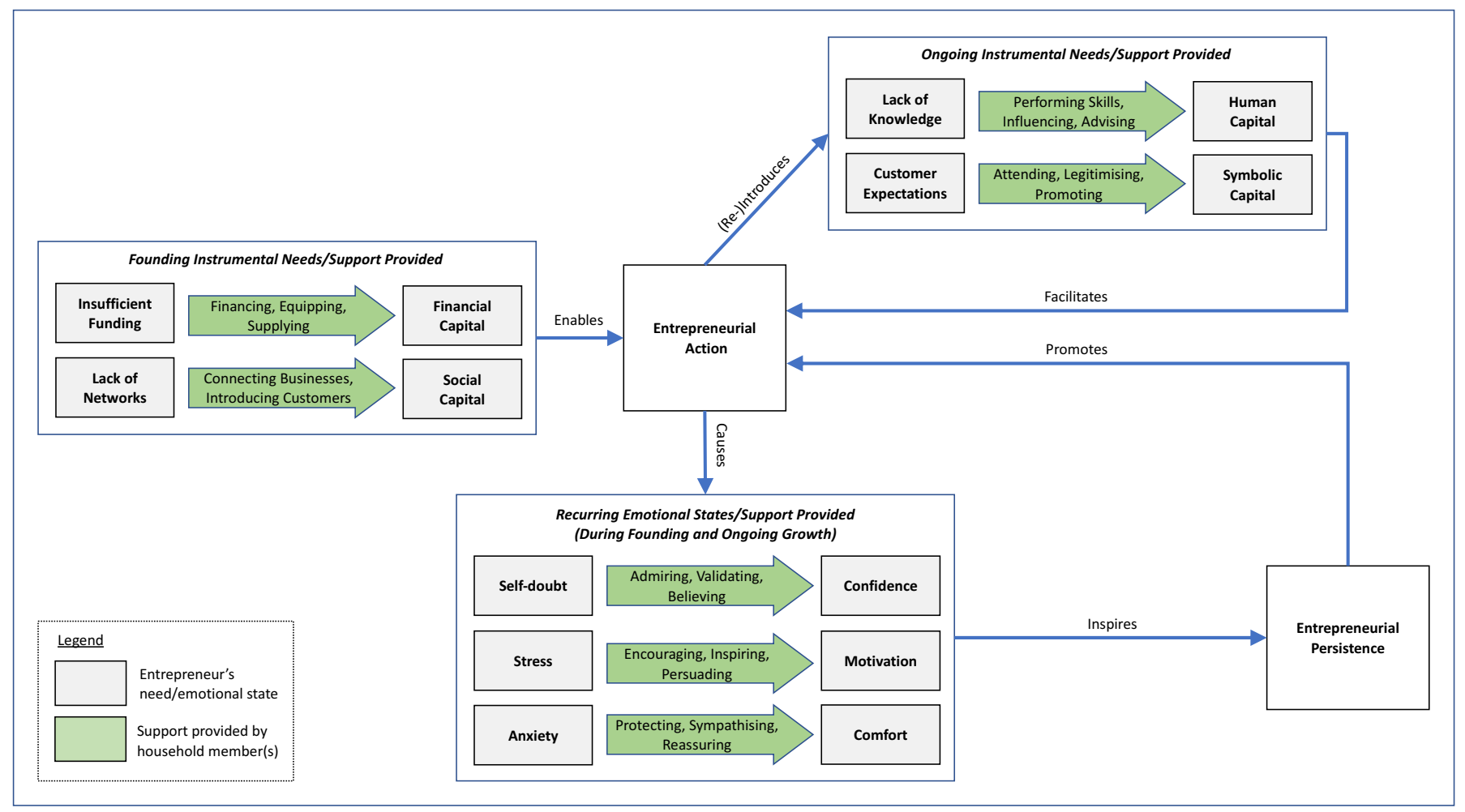

Specifically, we find that cohabitants support entrepreneurs through the provision of various forms of capital and emotional support, which helps them to start and grow their businesses, as well as cope with feelings of self-doubt, stress and anxiety which arise over time. The ongoing support of cohabitants enables entrepreneurs to continuously engage in entrepreneurial action. The provision of instrumental support facilitates this directly by granting entrepreneurs the resources required to pursue their objectives, while the provision of emotional support facilitates this indirectly through promoting persistence. Importantly, by facilitating entrepreneurial action and persistence, the need for household instrumental and 
emotional support is reaffirmed, creating a cyclical and continuous, rather than linear and terminal process.

An example of the recurring and everyday nature of the household support process after start-up is displayed in Figure $3 .{ }^{3}$ Representing the lived experiences of participants and adopting a strong process orientation (Langley and Tsoukas, 2016), this model depicts how social support from the household is performed through daily instrumental and emotional support activities which are triggered by entrepreneurs. It illustrates our finding that this process becomes incorporated into the fabric of participants' day-to-day entrepreneurial practices. We now delve further into how and when entrepreneurs and their households engage in instrumental and emotional support during the entrepreneurial process.

Figure 3. The Recurring and Everyday Nature of the Household Support Process

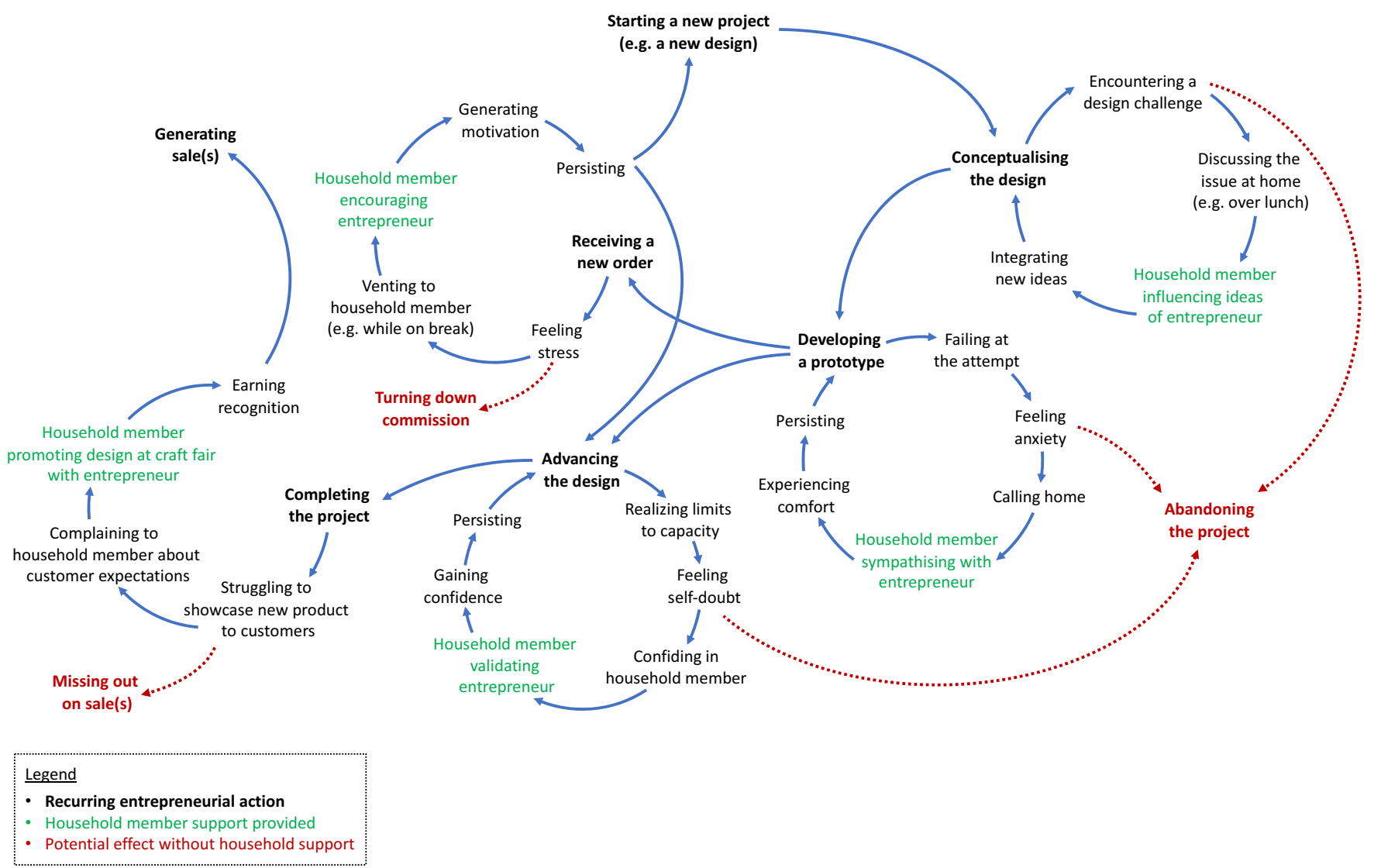

\section{Household instrumental support}

Our data reveal that, during start-up, artisan entrepreneurs primarily draw upon the financial and social capital support of cohabitants to engage in the entrepreneurial actions required to

\footnotetext{
${ }^{3}$ For the purposes of this study, we define the start-up phase as the period before artisans open their studios.
} 
establish their ventures. Subsequently, they rely on human and symbolic capital support from the household to continue growing their businesses over time.

Founding instrumental support: Financial capital. As shown in Table 3, participants gained financial capital support in the form of money, equipment and material from their household members. Several participants were given monetary assets as gifts, which allowed them to finance their launch while maintaining their financial independence. ${ }^{4}$ As Julie explains, ' $I$ would never take a loan, I would never spend money that I didn't have'. Importantly, participants were found to reject financial contributions post-start-up: 'he [Isaac, spouse], financially, doesn't support my business at all' (Isabel), mainly because they want to avoid breaking into the savings of the household: 'I'm not dipping into the family coffers' (George).

Table 3. Founding Instrumental Support: Financial Capital

\section{$\mathbf{1}^{\text {st }}$ Order Code Representative Quotation}

Financing 'Clara [partner] supported me financially, especially at the start, 'cos I wouldn't have been able to ... start the business if she hadn't had a decent paying job and been willing to live on one income to start with'. (Carol)

'A few years ago, he [Daniel, partner] helped me with my first rent for the workshop'. (Diana)

Equipping 'Evan [spouse] helped me ... refurbish the studio'. (Emily)

'He [Felix, cohabitant] gave me his old car ... so that's really helpful, 'cos ... I do need a reliable car for the business, because ... I do go around and deliver things'. (Frank)

Supplying 'He [Adam, partner] said, "Do you want some legs?" [laughs] ... 'cos at his college they were ... getting rid of a load of mannequins, so he ... brought them to me'. (Amy)

'I got lots of Harris tweed and different things from him [Evan, spouse]'. (Emily)

Furthermore, participants received valuable tangible assets from their cohabitants at this stage, as discussed by Frank: 'he [Felix, cohabitant] gave me the pug mill ... which is the big clay mixing machine over there'. Household members also supplied them with free materials, as illustrated by Betty: 'She's [Brenda, partner] got big, massive dresses that she inherited from her grandma ... which I used to create the first puppets for my books'. Although participants communicated that they would not reject gifts of material or equipment post-startup, they shared that these were neither common nor significant to them in later stages and that they only actively sought such support during start-up.

\footnotetext{
${ }^{4}$ Although cohabitants were also interviewed in this study, the term 'participant' is only used in reference to the entrepreneurs to avoid any misunderstandings.
} 
Founding instrumental support: Social capital. Social capital support, in the form of new connections brokered by household members (see Table 4), is of lesser importance to participants than other forms of instrumental support. This is largely due to the fact that their cohabitants are 'not involved in the art world at all' (Carol). Consequently, the utility of household members' social capital support is largely limited to the start-up phase, when entrepreneurs lack business networks and rely on whatever connections they can access to get started. As Amy describes, 'He [supplier] designed the logo at a cheaper cost than normal, but his work was amazing ... and if I hadn't known Adam [partner], I wouldn't have got that'.

Table 4. Founding Instrumental Support: Social Capital

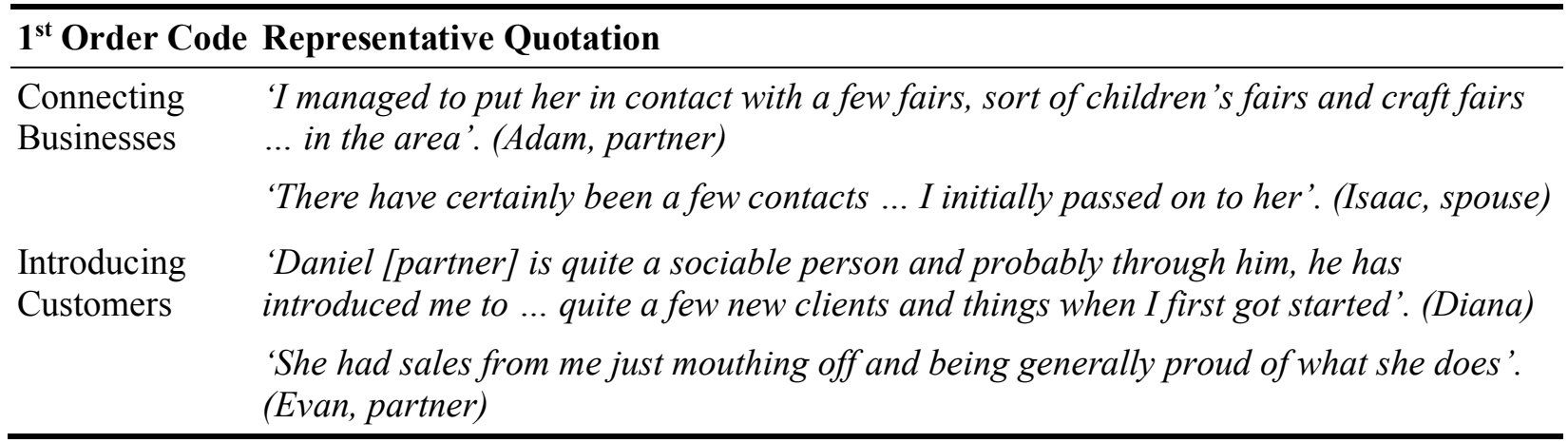

Household members also introduced artisan entrepreneurs to some of their first customers. As Emily reports, 'I got custom through him [Evan, partner]. He works at the council and it's a big kind of office building ... a lot of people found out about my business'. Without such confirmation that people were interested in buying their products, participants may not have pursued business start-up. Thus, despite their lack of connection to the creative world, social capital support of household members was decidedly valuable to participants during start-up.

Ongoing instrumental support: Human capital. As shown in Table 5, participants benefit considerably from the skills and advice of cohabitants, and they continuously draw on such help to pursue their business objectives over time. Of particular note, artisan entrepreneurs often rely on household members to perform technical skills to run and grow their businesses. Indeed, some of this skilled assistance, such as website maintenance, is essential to their daily operations. As Amy admits, 'I couldn't do that without him [Adam, partner]. I mean, I'd end up spending a fortune ... paying someone to maintain the website ... so I'm really lucky that he can do that'. However, Amy's evolving situation equally reflects the disadvantages of dependence 
on household members for such crucial skills. After breaking up with Adam (partner) towards the end of our study, she explained that 'I can't really rely on him anymore for that'. Consequently, she needed to hire a web developer to help maintain her website.

Table 5. Ongoing Instrumental Support: Human Capital

\begin{tabular}{ll}
\hline $\mathbf{1}^{\text {st }}$ Order Code Representative Quotation \\
\hline Performing & 'He [son] did all the photography for my books, he is very good at editing, he is much \\
Skills & better at spelling and grammar than I am'. (Julie) \\
& 'I usually do her tax return for her, 'cos she is even worse at accounting than me'. \\
(Brenda, partner) & \\
Influencing & 'He [Felix, cohabitant] gives me criticism of what I'm doing and things and says what \\
he likes and stuff'. (Frank) \\
'I've always sort of tried helping out in a sense, if I've looked at something and said \\
'Have you ever thought of, I don't know, changing that buckle?' or I've sent her through \\
inspirational pictures that I thought she might like'. (Adam, partner) \\
'The majority of my customers are so nice that when you get one who is a problem \\
customer you kind of don't know how to deal with that ... I have said, 'I can't believe \\
this e-mail, Clara [partner] you have to read it and tell me how to answer it"'. (Carol) \\
'I sort of ask him [Daniel, partner] ... for business advice sometimes, 'cos he is not a \\
creative person, but he is very practical, which I'm not always'. (Diana)
\end{tabular}

Surprisingly, participants do not attempt to learn these essential skills from their household members, but rather depend upon their help over time. As Holly explains, 'I don't have time and I don 't have any interest ... in learning how to do my tax return'. The only types of skills that artisan entrepreneurs seem to value enough to acquire themselves relate to their creative practice. As Brenda (partner) recounts, 'I have shown her [Betty] how to properly use a couple of tools for the leather'.

Another form of human capital support that cohabitants provide is creative insight. As Diana explains, 'it's sometimes helpful for someone who is not involved in this [craft] world in any way to kind of bring a different perspective to it'. Given that participants constantly have to develop new ideas to maintain client interest and reach new markets, the need for creative input never abates once they have started up. Furthermore, they regularly benefit from the business advice of household members, as illustrated by Carol:

Financial stuff I will ask her advice about because she [partner] is more sensible than I am ... I think often you find with creative people they are not always the most business savvy, or the most organised people [laughs], so yeah ... if I'm struggling ... I'll ask for her advice. 
Interestingly, participants made little reference to such support during the start-up phase. Although they acknowledged discussing their plans with cohabitants at this time, they largely considered their early-stage decisions to be based on their own ideas and efforts. Once their ventures were established, however, participants increasingly asked for advice, as they learned to appreciate the help and outside perspectives of their household members.

Ongoing instrumental support: Symbolic capital. As shown in Table 6, artisan entrepreneurs also consistently rely upon symbolic capital support from their cohabitants. While household members do not have their own symbolic capital that they lend to participants, customer expectations necessitate that they visibly work to generate status, reputation and prestige for the entrepreneurs.

Table 6. Ongoing Instrumental Support: Symbolic Capital

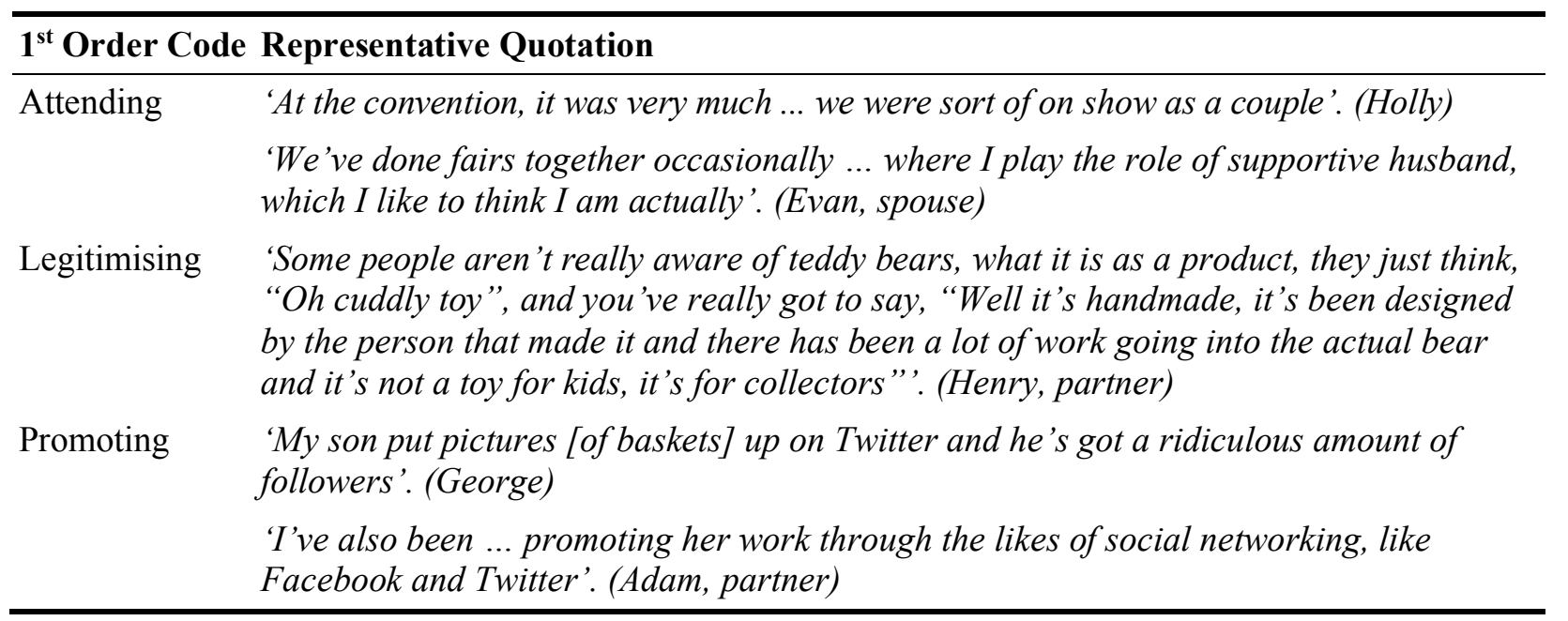

One way that cohabitants accomplish this is by attending shows and exhibitions to publicly perform the role of the 'happy, supportive family'. As Carol explains,

It's not just about the making [at shows], it's the kind of family, as well ... Even [famous maker] goes along with his wife and you meet ... his son, you meet ... the whole family and it is one big happy family really, everyone gets along.

The importance of family attendance at such exhibitions demonstrates how significant perceptions of 'family values' are to successful craft ventures. As such, household members 
are never free from the sense of obligation to promote this positive image and artisan entrepreneurs rely on their help to maintain it.

Household members also directly help improve the reputation of entrepreneurs through legitimising and promoting their work. While participants could potentially accomplish this task on their own, it can be difficult for them to fulfil customer expectations to continuously self-promote, while also maintaining a reputation as humble and accomplished crafters. As Diana illustrates,

Something as simple as you're out of an evening ... especially when you are selfemployed, you are never really away from your work, there is always somebody who wants to talk about what you do and ... I'm just kind of like, 'This is what I do', and that's it, whereas Daniel [partner] will be the one who will say, 'Well, you know, she has done this and ... that', and he will be the one promoting.

Because their household members are proactive in taking on such tasks, participants are able to relinquish some of this work and grow to rely on this support over time. Indeed, as we observed at multiple craft fairs, household members appear to fulfil customer expectations on behalf of entrepreneurs out of a sense of protection and pride.

\section{Household emotional support}

In addition to instrumental support, artisan entrepreneurs highly value emotional support from household members, because emotions are core to their creative abilities. As Emily acknowledges, 'I rely so much on her [daughter] ... because I'm a very emotional person ... and because I know that my work is so much linked to ... the mood I'm in'. Emotional support was found to be perpetually important from initial venture creation to ongoing business growth, as artisan entrepreneurs repeatedly cycle between high and low emotional states while they develop their businesses. Thus, by facilitating persistence, the emotional cycles that entrepreneurs experience are sustained and the continuous need for household support is thereby reinforced. Our data reveal that cohabitants particularly provide artisan entrepreneurs with confidence, motivation and comfort.

Recurring emotional support: Confidence. Artisan entrepreneurs were found to experience self-doubt on a regular basis. Participants shared that they often question their creative talents, feel like they are not good enough or that they will not succeed in their businesses. Interestingly, such feelings are not limited to when participants first start their ventures, 
make errors or experience slumps in sales, but also emerge when, by all accounts, things are running smoothly and opportunities abound. As Isabel explains, 'you will have odd moments and that's when you do need ... [your spouse] to help you ... just to bridge that gap of confidence', and as Betty shared, 'I had sort of moments with depression ... and without that support, you know, I don't think I would have ... gone through them or I wouldn't have got through them as well'.

As shown in Table 7, at these times, cohabitants boost the confidence of artisan entrepreneurs by admiring their products, validating their choices and abilities and affirming their belief in them. For example, Brenda (partner) proclaims her conviction that Betty will succeed by declaring, 'the stuff she designs is amazing ... she just has all these ideas that come out of her head and ... when she executes them they are really good'. Because artisan entrepreneurs need to continuously develop their styles to retain customer interest, they need to believe in their creative abilities. Therefore, as Isabel expresses, 'I think it's when your confidence is knocked, that probably is the most important time when you need emotional support'.

Table 7. Recurring Emotional Support: Confidence

\begin{tabular}{ll}
\hline $\mathbf{1}^{\text {st }}$ Order Code & Representative Quotation \\
\hline Admiring & 'I comment on how nice things are, how well executed they are'. (Evan, spouse) \\
& 'The finished products that he comes up with, they are always amazing ... stuff that \\
& blows me away every time'. (Grace, spouse) \\
Validating & 'Sometimes I just need Daniel [partner] ... to validate the decision that I've made or to, \\
& you know, kind of go 'Yeah, that is a good plan"' (Diana) \\
& 'She needs a confidence boost; she needs to be told how artistic she is'. (Henry, partner) \\
Believing & 'She [Brenda, partner] ... has tremendous belief in me, even if I don't have belief in \\
& myself sometimes'. (Betty) \\
& 'They support me in whatever I choose to do ... They trust that I'll do well at it'. (Amy) \\
\hline
\end{tabular}

Recurring emotional support: Motivation. In addition to self-doubt, participants explain that they routinely struggle with stress and that it is difficult to remain motivated when pressures pile up, such as 'when I am stressed before a show' (Holly) or 'when I'm all stressed out and running into a deadline' (Amy). Participants do not have colleagues to help with their workloads. Instead, they rely upon their household members to encourage, inspire and persuade them to achieve their goals (see Table 8). 
Table 8. Recurring Emotional Support: Motivation

\begin{tabular}{|c|c|}
\hline \multicolumn{2}{|c|}{$1^{\text {st }}$ Order Code Representative Quotation } \\
\hline \multirow[t]{2}{*}{ Encouraging } & 'They are brilliant really ... they are always very encouraging'. (Amy) \\
\hline & $\begin{array}{l}\text { 'Clara [partner] is very supportive ... She can, you know, kind of encourage me to keep } \\
\text { doing the thing that I'm doing'. (Carol) }\end{array}$ \\
\hline \multirow[t]{2}{*}{ Inspiring } & $\begin{array}{l}\text { 'When you see your child have ... a large degree of success, that gives you a huge } \\
\text { amount of buzz ... it's almost as if someone [says] ... "You can do it, too". (Isabel) }\end{array}$ \\
\hline & $\begin{array}{l}\text { 'My partner ... sometimes passes on comments, which can be useful in the sense that } \\
\text { they are either triggers or kicks up the arse'. (Betty) }\end{array}$ \\
\hline \multirow[t]{2}{*}{ Persuading } & $\begin{array}{l}\text { 'Sometimes you can get a wrap over the knuckles and ... "For goodness sake, mum, } \\
\text { what's your problem? Just get on with it!" which is quite often what you need'. (Julie) }\end{array}$ \\
\hline & $\begin{array}{l}\text { 'I just supported her and gave her a little push to say "What's the harm in trying it, you } \\
\text { can always back out if it doesn't work out"'. (Brenda, partner) }\end{array}$ \\
\hline
\end{tabular}

As Frank explains, 'It's quite hard in the workshop to get motivated ... when it's cold and damp ... so in some ways, you know, Felix [cohabitant] ... getting ready and going to work every day kind of motivates me ... [to] get started'. Given that their work relies on their creative energy, being motivated to continue producing their crafts and developing new ideas is essential for the success of participants. As Julie explains,

the pressure of continuing to create something new when you're feeling well and on top of things, you know, it's not an effort; but, when the pressure starts to get to you, I suppose that's when you need emotional support the most.

Significantly, as participants gain recognition and broaden their product lines, the pressures they experience increase, rather than decrease. As sole proprietors, all extra creative work falls entirely on their shoulders. Thus, stress appears to become a more prevalent issue the further participants grow their businesses, leading them to increasingly call upon the motivational support of their household members over time.

Recurring emotional support: Comfort. Another recurring emotional state that participants frequently experience is anxiety. Various worries, such as the prospect of starting up, meeting the evolving expectations of customers and launching new product lines, emerged for participants. Though the focus of their anxieties changes as their businesses grow, they do not appear to abate over time. By providing a sense of security and expressing their sympathy and reassurance, cohabitants comfort entrepreneurs and help them overcome their fears and bounce back from bouts of anxiety (see Table 9). 
Table 9. Recurring Emotional Support: Comfort

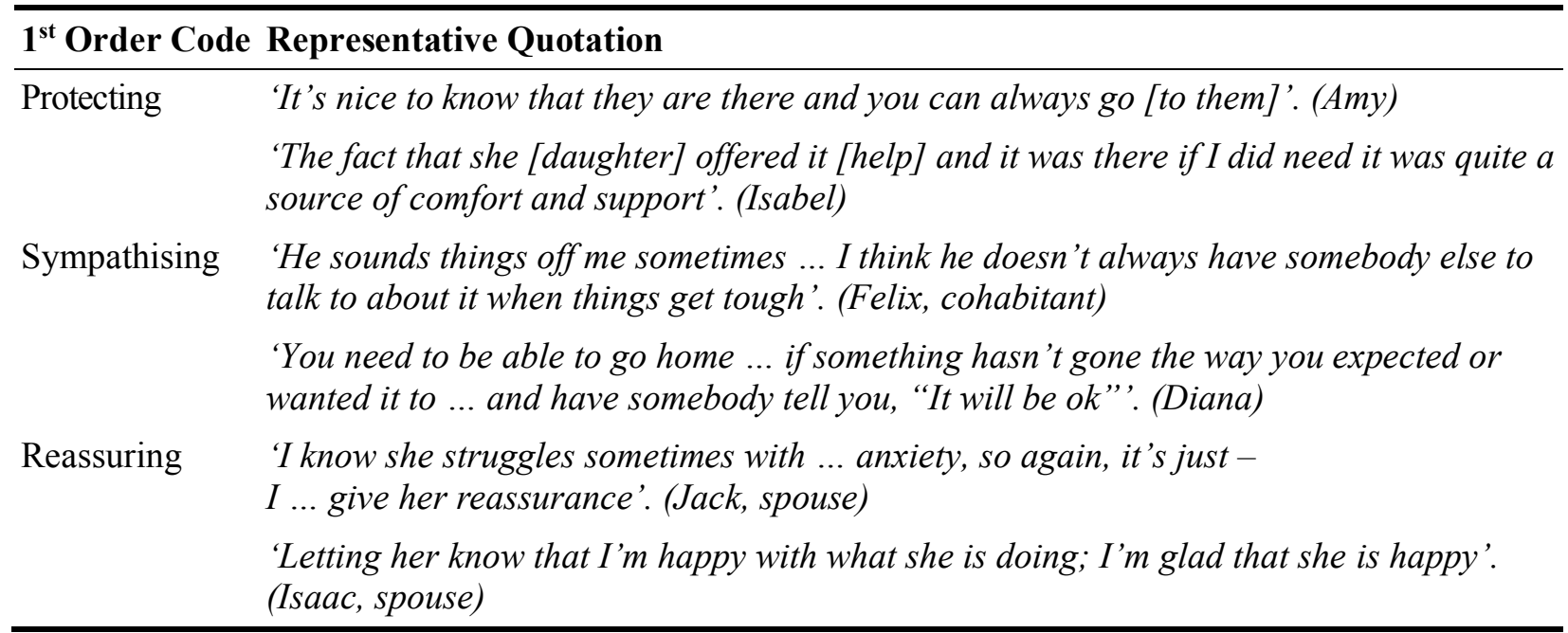

Participants rely on the comfort that household members provide to develop persistence in the face of worries they cannot cope with alone, as illustrated by Isabel: 'I think everybody needs their wailing wall occasionally ... to unload and vent and then move on'. Comfort can be both explicit, such as when participants feel so overwhelmed that they 'hit a brick wall ... that's when my family ... has to pick me up' (Emily), or implicit, such as the very fact that 'I know it's there when I need it [emotional support], so, you know, if it wasn't, I would probably flounder quite a bit' (Holly).

Diana most clearly articulates why it is the emotional support from cohabitants in particular that she values so highly: 'because he [Daniel, partner] has been there from the very beginning ... he has seen how I have grown and how the work has grown ... and [therefore] has a greater understanding and knowledge of what's involved'. Similarly, Grace (spouse) discloses, 'I think he [George] probably appreciates my help more than he would most people, simply because I probably understand him ... better than most people do'. In other words, understanding is key to effective social support. It is thus evident that the utility of household support is self-perpetuating: by actively engaging with cohabitants, entrepreneurs ensure that household members more fully understand them and their businesses, making social support from the household increasingly valuable.

\section{Discussion and Implications}

Our findings offer three main theoretical contributions to the social support and entrepreneurship literatures. First, we reveal that social support from the household is a dynamic, ongoing process which is core to the abilities of entrepreneurs to pursue venture start- 
up and growth over time. Second, we demonstrate that social support from the household is interactive, whereby households participate in the journeys of entrepreneurs on an everyday basis. Third, we show that the often considered contradictory main effect and buffering mechanisms of social support are actually interdependent. We discuss each of these contributions below in relation to the extant literature.

\section{Social support as process}

Diverging from the dominant trend of focussing on its outcomes (Bavik et al., 2020; Taylor, 2011), we highlight that social support is a process that changes over time and is continuously underway. Specifically, our longitudinal study reveals that household members and entrepreneurs enact social support on a daily basis through performing support activities and relying on this support to engage in entrepreneurial action and generate persistence (as illustrated in Figure 2). Social support from the household is therefore shown to be a continuous endeavour rather than an attribute entrepreneurs attain (Brüderl and Preisendörfer, 1998).

To date, entrepreneurship research has predominately approached social support in the form of household capital as a stagnant pool of resources (cf. Caputo and Dolinsky, 1998; Wheelock and Oughton, 1996) and largely overlooked its processual nature (Klyver et al., 2018). Instead, we demonstrate that instrumental support activities change over time. Our findings confirm the well-documented importance of financial capital support during start-up (Brush et al., 2001; Lee and Persson, 2016). However, we challenge the assumption that financial support from the household continues to be important (Braun and Sieger, 2021) by demonstrating that artisan entrepreneurs avoid relying on it post-start-up, not because they fear indebtedness (Steier, 2009), but to protect the household's savings. In finding that the need for social capital support from households is similarly limited to the start-up period, our study empirically supports the hypothesis that entrepreneurs may grow to rely less on this support as they develop their own networks (Edelman et al., 2016). As such, these forms of instrumental support are shown to be a short-lived part of the longer social support process.

We highlight that this longer process involves ongoing human and symbolic capital support, as well as recurrent emotional support. Our findings show that these forms of support are not simply utilised to fill a gap when other resources are scarce (Brüderl and Preisendörfer, 1998) or when entrepreneurial identity issues arise (Klyver et al., 2018), but are rather an ongoing part of the daily activities of entrepreneurs and become embedded in the very fabric of the entrepreneurial process (as illustrated in Figure 3). Both human and symbolic capital support were revealed as essential in enabling recurring entrepreneurial actions, such as 
developing new prototypes or advancing designs. Importantly, core to the effectiveness of human and symbolic capital support was the entrepreneur's ability to continuously rely on these forms of support.

In contrast to most entrepreneurship studies which simply acknowledge the importance of emotional support from the household (Alsos et al., 2014; Danes et al., 2009), we elucidate its processual and dynamic nature. The limited research on the temporality of emotional support shows that it is most useful during the nascent venture stage (Brüderl and Preisendörfer, 1998), when prospective entrepreneurs struggle to take the leap into self-employment (Klyver et al., 2018). Our findings affirm the importance of emotional support during start-up, but we also emphasise that this support is needed throughout the cyclical emotional struggles that entrepreneurs experience as they grow their businesses. As such, our findings challenge extant research which suggests that emotional support becomes less useful over time and acts as a break on venture growth (Arregle et al., 2015). Given that several of our participants are over 50 , this study also questions research which proposes that older entrepreneurs are less likely to require emotional support (Klyver et al., 2018).

\section{Social support as interactive}

The second main contribution of this study is to demonstrate the highly interactive character of social support from the household. In so doing, we help unpack the relationship between households and entrepreneurship (Alsos et al., 2014; Meliou and Edwards, 2017). Our findings show that households are not merely a supplementary source of resources (Danes et al., 2009; Kotha and George, 2012), but instead are collaborative partners upon whom entrepreneurs rely to actively support their business development.

Whereas extant research demonstrates that entrepreneurs seek to acquire human capital, such as essential business skills, from their households (Bird and Wennberg, 2016; Carter et al., 2017), indicating that interaction is limited to exchange, our participants show no interest in learning skills that are not directly related to their creative practice. Instead, they continue to proactively ask for human capital support from household members, revealing that entrepreneurs are not simply passive recipients of social support (Gras and Nason, 2015), but active participators in this interpersonal process.

Within the context of artisan entrepreneurship, symbolic capital support from the household was shown to be particularly interpersonal and interactive. Our findings highlight that household members play a core role in developing the reputations of entrepreneurs as a result of customer expectations which require household members to visibly perform the role 
of the 'happy, supportive family'. Our study, therefore, reveals that industry norms not only influence the practices of artisan entrepreneurs (Pret and Carter, 2017), but also the dynamics within their households. By demonstrating that household members may be expected to play an ongoing, active role in building the symbolic capital of entrepreneurs, we also challenge the traditional understanding that entrepreneurs can and should seek ownership of all the forms of capital they utilise (Drakopoulou Dodd et al., 2016; Pret et al., 2016).

Furthermore, our findings emphasise the interactivity that lies at the heart of emotional support, which has been largely overlooked in the entrepreneurship literature (Jennings et al., 2015). Specifically, we show that, to deal with negative emotional states, such as stress and anxiety, emotional support requires active and purposeful efforts from both entrepreneurs and household members. On the one hand, entrepreneurs seek out help from cohabitants and actively involve them in their problems and ventures. On the other, cohabitants tailor their emotional support to the particular emotional state and needs of the entrepreneur at a given moment. Given that entrepreneurs continue to solicit and rely on emotional support over time, our findings question the assumption that entrepreneurs increasingly learn how to deal with emotional challenges on their own (Arregle et al., 2015; Klyver et al., 2018). Indeed, we find that such social support is deeply integrated into the everyday practices of entrepreneurs (as illustrated in Figure 3), and therefore plays a primary, rather than auxiliary role in entrepreneurship. Thus, rather than being a passive feeling of 'caring, acceptance and respect' (Fielden and Hunt, 2011: 347), we demonstrate that emotional support is an endeavour that requires not only social skills (Nielsen and Klyver, 2020), but also sustained interaction, trust and commitment from both entrepreneurs and household members equally.

\section{Reconciling the main effect model and buffering hypothesis of social support}

The third main contribution of this study lies in extending both the main effect and buffering models of social support by suggesting that they are interdependent. While social support has been theorised as either operating on an ongoing basis (main effect model) or as a cushion against distinct stress events (buffering hypothesis) (Cohen and Wills, 1985; Suurmeijer et al., 1995), we suggest that, rather than being contradictory, these mechanisms are complementary and intertwined.

First, our findings highlight that social support is continually beneficial because it is an ongoing process that is entrenched in the lives of entrepreneurs and their households and enables daily entrepreneurial actions and persistence, thus supporting the main effect model (Thoits, 1982). Second, we clearly demonstrate that social support from the household also acts 
as a buffer against problems: by providing instrumental and emotional support, households help entrepreneurs overcome both everyday and atypical occurrences of stress and need, substantiating the buffering hypothesis (Cassel, 1976; Cobb, 1976). Not only do our findings suggest that both models may coexist, but they also indicate that these mechanisms are mutually constitutive: the stress-moderating effects of social support (buffering hypothesis) seem to occur because of the ongoing social integration of entrepreneurs and their households (main effect model), which is itself enabled by practicing problem-oriented social support (buffering hypothesis).

By making the social support process a central part of their relationship, entrepreneurs and their households become interdependent through these daily, intimate interactions. While the benefits that result from a high degree of social integration have traditionally been categorised as main effects (Cohen and Wills, 1985; LaRocco et al., 1980), we show that artisan entrepreneurs experience the buffering effects of social support as effective only because of this interdependence, demonstrating that the two models of social support are not so easily separable and clearly not contradictory.

Indeed, our data indicate that stress-buffering and main effects may not only be intertwined but also, in some contexts, one and the same. Our findings regarding the recurring emotional states and support needs of entrepreneurs highlight the everyday and cyclical nature of stress, self-doubt and anxiety, which have largely been overlooked in the extant literature (Cardon et al., 2012; Lerman et al., 2021). Emotional support from households through the regular provision of confidence, motivation and comfort emerged as pivotal in overcoming these emotional lows and maintaining entrepreneurial persistence (as outlined in Figure 2). Though clearly acting as a negativity buffer (Bavik et al., 2020), this emotional support was found to be an ongoing, consistent process that was embedded in the everyday interactions of households. Our study therefore extends the conversation about whether entrepreneurs are more or less stressed than non-entrepreneurs (Baron, et al., 2013; Cardon and Patel, 2015) by suggesting that ongoing stress-buffering through emotional support is a necessary requirement of entrepreneurial persistence. Not only does this study reveal that emotional support may be far more integral to the process of entrepreneurship than is currently assumed (Danes et al., 2009), but also that, in certain high-stress contexts, stress-buffering may become a main effect of social support. 


\section{Limitations and future research}

There are several avenues for future research based on this study's limitations. First, we investigated the uni-directional support given by household members to entrepreneurs. Future research could explore how entrepreneurs engage in social support of their household members or the dynamics of bi-directional social support exchanges. Second, by selecting participants who did not have children under the age of 10 , we may have prevented potentially interesting discussions related to early parenthood and its effects on social support in the household (Jayawarna et al., 2020; Naldi et al., 2021; Ogundana et al., 2021). Gaining insights into such experiences could further improve understanding of the interactions between household and business.

Furthermore, by investigating the experiences of entrepreneurs who successfully established and continue to grow their businesses, our study finds largely positive examples of the household support process. However, we recognise that household or family members may also provide discouragement (Treffers et al., 2019). Future investigations into how entrepreneurs are able to act despite discouragement from household members, as well as studies that explore the household support of entrepreneurs who experience failed ventures may illuminate different social support processes than those found in our study.

\section{Implications for policy and practice}

The findings of this study also carry practical implications. First, entrepreneurs are encouraged to view their household members not only as potential sources of funding for their ventures, but as partners in business growth. Cohabitants were shown to help artisan entrepreneurs develop their ventures in various ways, such as by offering business advice and promoting their ventures. Even if household members are not knowledgeable about all business activities, their support can still benefit entrepreneurs, such as through provision of an outside perspective. Second, understanding between cohabitants and entrepreneurs appears to determine the value of emotional support. Expressions of admiration, reassurance and encouragement (among others) induce confidence, motivation and comfort, and thus facilitate persistence, but only if cohabitants truly understand entrepreneurs and what they are going through. As such, entrepreneurs should ensure that they maintain strong household relationships. Our findings suggest that one way of doing so is for entrepreneurs to regularly involve household members in their businesses by calling upon their support.

Given the significant roles that household instrumental and emotional support play in facilitating entrepreneurial actions and persistence, policy makers are urged to provide 
entrepreneurs with support mechanisms, such as paid leave to care for ill family members, so that entrepreneurs can maintain household relationships without detriment to their businesses. The public sector could also try to emulate household emotional support by offering services, such as therapeutic counselling, to allow entrepreneurs who lack household support to gain emotional assistance.

\section{Conclusion}

We set out to investigate how and when instrumental and emotional support from household members facilitate entrepreneurial action and persistence. Our findings show that social support from the household is not a supplementary resource, but is instead a core element of entrepreneurs' abilities to pursue venture start-up and growth over time. The conceptual framework we develop illustrates how social support from the household becomes embedded in entrepreneurial practice by continuously facilitating action and persistence. As such, we reveal social support as a dynamic, ongoing process, rather than a static resource. Our study also highlights the interactive nature of the social support process. We find that households actively participate in the journeys of entrepreneurs on an everyday basis by catering to their emergent instrumental needs through provision of household capital support and to their cycling emotional states through emotional support. We demonstrate that entrepreneurs are not passive recipients of this support, but purposefully seek it out. Finally, we identify the mechanisms of social support as complementary, rather than contradictory, finding that the main effect and buffering models of social support are interdependent.

\section{References}

Adams GA, King LA and King DW (1996) Relationships of job and family involvement, family social support, and work-family conflict with job and life satisfaction. Journal of Applied Psychology 81 (4): 411-420.

Aldrich HE and Cliff JE (2003) The pervasive effects of family on entrepreneurship: toward a family embeddedness perspective. Journal of Business Venturing 18 (5): 573-596.

Alsos GA, Carter S and Ljunggren E (2014) Kinship and business: how entrepreneurial households facilitate business growth. Entrepreneurship \& Regional Development 26 (1-2): 97-122.

Arregle J-L, Batjargal B, Hitt MA, et al. (2015) Family Ties in Entrepreneurs' Social Networks and New Venture Growth. Entrepreneurship Theory and Practice 39 (2): 313-344.

Baron RA, Franklin RJ and Hmieleski KM (2013) Why Entrepreneurs Often Experience Low, Not High, Levels of Stress: The Joint Effects of Selection and Psychological Capital. Journal of Management 42 (3): 742-768.

Barrera M (1986) Distinctions between social support concepts, measures, and models. American Journal of Community Psychology 14 (4): 413-445. 
Bavik YL, Shaw JD and Wang X-H (2020) Social Support: Multidisciplinary Review, Synthesis, and Future Agenda. Academy of Management Annals 14 (2): 726-758.

Berglund H (2007) Researching Entrepreneurship as lived experience. In: Neergaard H and Ulhøi JP (eds) Handbook of qualitative research in entrepreneurship. Cheltenham: Edward Elgar, pp. 75-93.

Bird M and Wennberg K (2016) Why family matters: The impact of family resources on immigrant entrepreneurs' exit from entrepreneurship. Journal of Business Venturing 31 (6): 687-704.

Bourdieu P (1977) Outline of a Theory of Practice (Nice R, Trans.). Cambridge, MA: Cambridge University Press.

Braun I and Sieger P (2021) Under pressure: Family financial support and the ambidextrous use of causation and effectuation. Strategic Entrepreneurship Journal 15(4): 716-749.

Broadhead WE, Kaplan BH, James SA, et al. (1983) The epidemiologic evidence for a relationship between social support and health. American Journal of Epidemiology 117 (5): 521-537.

Brüderl J and Preisendörfer P (1998) Network support and the success of newly founded businesses. Small Business Economics 10 (3): 213-225.

Burns J, Gibbon C, Rosemberg C, et al. (2012) Craft in an Age of Change. London: Crafts Council.

Brush CG, Greene PG and Hart MM (2001) From initial idea to unique advantage: The entrepreneurial challenge of constructing a resource base. Academy of Management Executive 15 (1): 64-78.

Caputo RK and Dolinsky A (1998) Women's choice to pursue self-employment: The Role of financial and human capital of household members. Journal of Small Business Management 36 (3): 8-17.

Cardon MS, Foo M-D, Shepherd D, et al. (2012) Exploring the Heart: Entrepreneurial Emotion Is a Hot Topic. Entrepreneurship Theory and Practice 36 (1): 1-10.

Cardon MS and Kirk CP (2015) Entrepreneurial Passion as Mediator of the Self-Efficacy to Persistence Relationship. Entrepreneurship Theory and Practice 39 (5): 1027-1050.

Cardon MS and Patel PC (2015) Is Stress Worth it? Stress-Related Health and Wealth TradeOffs for Entrepreneurs. Applied Psychology 64 (2): 379-420.

Carter S (2011) The Rewards of Entrepreneurship: Exploring the Incomes, Wealth, and Economic Well-Being of Entrepreneurial Households. Entrepreneurship Theory and Practice 35 (1): 39-55.

Carter S, Kuhl A, Marlow S, et al. (2017) Households as a site of entrepreneurial activity. Foundations and Trends in Entrepreneurship 13 (2): 81-190.

Cassel, JC (1976) The Contribution of the Social Environment to Host Resistance. American Journal of Epidemiology 104 (2):107-123.

Chen Y and Klyver K (2021) Keeping a keen edge: Social support among new venture team members and venture goal commitment. Journal of Small Business Management. Epub ahead of Print 16 March. DOI: 10.1080/00472778.2021.1883040.

Cobb S (1976) Social Support as a Moderator of Life Stress. Psychosomatic Medicine 38 (5): 300-314.

Cogan A and Pret T (2020) True Colors: Pursuing Social Entrepreneurship as Verifying Identity Work. Frontiers of Entrepreneurship Research 40(13): 307 - 312.

Cohen S, Gottlieb BH and Underwood LG (2000) Social relationships and health. In: Cohen S, Underwood LG and Gottlieb BH (eds) Social support measurement and intervention: A guide for health and social scientists. New York, NY: Oxford University Press, pp. 325 . 
Cohen S and Wills TA (1985) Stress, social support, and the buffering hypothesis. Psychological Bulletin 98 (2): 310-357.

Cope J (2005) Researching Entrepreneurship through Phenomenological Inquiry: Philosophical and Methodological Issues. International Small Business Journal 23 (2): 163-189.

Cope J (2011) Entrepreneurial learning from failure: An interpretative phenomenological analysis. Journal of Business Venturing 26 (6): 604-623.

Danes SM, Stafford K, Haynes G, et al. (2009) Family Capital of Family Firms: Bridging Human, Social, and Financial Capital. Family Business Review 22 (3): 199-215.

Davidsson P and Gruenhagen JH (2021) Fulfilling the Process Promise: A Review and Agenda for New Venture Creation Process Research. Entrepreneurship Theory and Practice 45 (5): 1083-1118.

Drakopoulou Dodd S, Pret T and Shaw E (2016) Advancing Understanding of Entrepreneurial Embeddedness: Forms of Capital, Social Contexts and Time. In: Welter F and Gartner WB (eds) A Research Agenda for Entrepreneurship and Context. Cheltenham: Edward Elgar, pp. 120-133.

Eddleston KA and Powell GN (2012) Nurturing Entrepreneurs' Work-Family Balance: A Gendered Perspective. Entrepreneurship Theory and Practice 36 (3): 513-541.

Edelman LF, Manolova T, Shirokova G, et al. (2016) The impact of family support on young entrepreneurs' start-up activities. Journal of Business Venturing 31(4): 428-448.

Edmondson AC and McManus SE (2007) Methodological Fit in Management Field Research. Academy of Management Review 32 (4): 1155-1179.

Fielden SL and Hunt CM (2011) Online coaching: An alternative source of social support for female entrepreneurs during venture creation. International Small Business Journal 29 (4): 345-359.

Foss NJ and Klein PG (2010) Alertness, Action, and the Antecedents of Entrepreneurship. Journal of Private Enterprise 25 (2): 145-164.

Goodwin R, Costa P and Adonu J (2004) Social support and its consequences: 'Positive' and 'deficiency' values and their implications for support and self-esteem. British Journal of Social Psychology 43 (3): 465-474.

Gottlieb BH and Bergen AE (2010) Social support concepts and measures. Journal of Psychosomatic Research 69 (5): 511-520.

Gras D and Nason R (2015) Bric by bric: The role of the family household in sustaining a venture in impoverished Indian slums. Journal of Business Venturing 30 (4): 546-563.

Greenman A (2012) Entrepreneurial activities and occupational boundary work during venture creation and development in the cultural industries. International Small Business Journal 30 (2): 115-137.

Greenman A (2013) Everyday entrepreneurial action and cultural embeddedness: an institutional logics perspective. Entrepreneurship \& Regional Development 25 (7-8): 631-653.

Holland D and Shepherd D (2013) Deciding to Persist: Adversity, Values, and Entrepreneurs' Decision Policies. Entrepreneurship Theory and Practice 37 (2): 331-358.

House JS, Umberson D and Landis KR (1988) Structures and Processes of Social Support. Annual Review of Sociology 14 (1): 293-318.

Jayawarna D, Marlow S and Swail J (2021) A Gendered Life Course Explanation of the Exit Decision in the Context of Household Dynamics. Entrepreneurship Theory and Practice 45 (6): 1394-1430.

Jack SL, Drakopoulou Dodd S and Anderson AR (2008) Change and the development of entrepreneurial networks over time: a processual perspective. Entrepreneurship \& Regional Development 20 (2): 125-159. 
Jennings JE, Edwards T, Jennings PD, et al. (2015) Emotional arousal and entrepreneurial outcomes: Combining qualitative methods to elaborate theory. Journal of Business Venturing 30 (1): 113-130.

Jennings JE and McDougald MS (2007) Work-family interface experiences and coping strategies: Implications for entrepreneurship research and practice. Academy of Management Review 32 (3): 747-760.

Johannisson B (2011) Towards a practice theory of entrepreneuring. Small Business Economics 36 (2): 135-150.

Kaplan BH, Cassel JC and Gore S (1977) Social Support and Health. Medical Care 15 (5): 47-58.

Kim PH, Longest KC and Aldrich HE (2013) Can You Lend Me a Hand? Task-Role Alignment of Social Support for Aspiring Business Owners. Work and Occupations 40 (3): 213-249.

Kimmitt J, Muñoz P and Newbery R (2020) Poverty and the varieties of entrepreneurship in the pursuit of prosperity. Journal of Business Venturing 35 (4): 105939.

Kirzner IM (1973) Competition and entrepreneurship. Chicago, IL: University of Chicago Press.

Klyver K, Honig B and Steffens P (2018) Social support timing and persistence in nascent entrepreneurship: exploring when instrumental and emotional support is most effective. Small Business Economics 51 (3): 709-734.

Klyver K, Schenkel MT and Nielsen MS (2020) Can't always get what I want: Cultural expectations of emotional support in entrepreneurship. International Small Business Journal 38 (7): 677-690.

Kotha R and George G (2012) Friends, family, or fools: Entrepreneur experience and its implications for equity distribution and resource mobilization. Journal of Business Venturing 27 (5): 525-543.

Kuhn KM and Galloway TL (2015) With a Little Help From My Competitors: Peer Networking Among Artisan Entrepreneurs. Entrepreneurship Theory and Practice 39 (3): 571-600.

Langley A and Tsoukas H (2016) Introduction: process thinking, process theorizing and process researching. In: Langley A and Tsoukas H (eds) The Sage Handbook of Process Organization Studies. London, UK: Sage, pp. 1-25.

LaRocco JM, House JS and French JRP (1980) Social Support, Occupational Stress, and Health. Journal of Health and Social Behavior 21 (3): 202-218.

Lee S and Persson P (2016) Financing from family and friends. Review of Financial Studies 29 (9): 2341-2386.

Lerman MP, Munyon TP and Williams DW (2021) The (not so) dark side of entrepreneurship: A meta-analysis of the well-being and performance consequences of entrepreneurial stress. Strategic Entrepreneurship Journal 15 (3): 377-402.

McIntosh C (2013) Cambridge Advanced Learner's Dictionary (4th ed.). Cambridge, UK: Cambridge University Press.

McKeever E, Jack SL and Anderson AR (2015) Embedded entrepreneurship in the creative re-construction of place. Journal of Business Venturing 30 (1): 50-65.

Meliou E and Edwards T (2017) Relational practices and reflexivity: Exploring the responses of women entrepreneurs to changing household dynamics. International Small Business Journal 36 (2): 149-168.

Naldi L, Baù M, Ahl H, et al. (2021) Gender (in)equality within the household and business start-up among mothers. Small Business Economics 56 (2): 903-918. 
Nielsen MS and Klyver K (2020) Meeting entrepreneurs' expectations: the importance of social skills in strong relationships. Entrepreneurship \& Regional Development 32 (910): 737-756.

Ogundana OM, Simba A, Dana L-P and Liguori E (2021) Women entrepreneurship in developing economies: A gender-based growth model. Journal of Small Business Management 59 (S1): S42-S72.

Packard MD (2017) Where did interpretivism go in the theory of entrepreneurship? Journal of Business Venturing 32 (5): 536-549.

Powell GN and Eddleston KA (2013) Linking family-to-business enrichment and support to entrepreneurial success: Do female and male entrepreneurs experience different outcomes? Journal of Business Venturing 28 (2): 261-280.

Powell GN and Eddleston KA (2017) Family Involvement in the Firm, Family-to-Business Support, and Entrepreneurial Outcomes: An Exploration. Journal of Small Business Management 55 (4): 614-631.

Pret T (2017) The Influence of Contexts on Entrepreneurial Practices: A Qualitative Study. Unpublished PhD thesis. Glasgow, UK: University of Strathclyde.

Pret, T (2022) Accumulation and Conversion of Capital: The Resource Management Practices of Entrepreneurs. Pathways to Research. Epub ahead of Print.

Pret T and Carter S (2017) The importance of 'fitting in': collaboration and social value creation in response to community norms and expectations. Entrepreneurship \& Regional Development 29 (7-8): 639-667.

Pret T and Cogan A (2019) Artisan entrepreneurship: a systematic literature review and research agenda. International Journal of Entrepreneurial Behavior \& Research 25 (4): 592-614.

Pret T, Shaw E and Drakopoulou Dodd S (2016) Painting the Full Picture: The Conversion of Economic, Cultural, Social and Symbolic Capital. International Small Business Journal 34 (8): 1004-1027.

Rodriguez P, Tuggle CS and Hackett SM (2009) An Exploratory Study of How Potential "Family and Household Capital" Impacts New Venture Start-Up Rates. Family Business Review 22 (3): 259-272.

Ruef M (2020) The household as a source of labor for entrepreneurs: Evidence from New York City during industrialization. Strategic Entrepreneurship Journal 14 (1): 20-42.

Sarasvathy SD (2021) The Middle Class of Business: Endurance as a Dependent Variable in Entrepreneurship. Entrepreneurship Theory and Practice 45 (5): 1054-1082.

Schumpeter JA (1942) Capitalism, socialism and democracy. New York, NY: Harper \& Row.

Shaw E, Wilson J and Pret T (2017) The process of embedding a small firm in its industrial context. International Small Business Journal 35 (3): 219-243.

Shepherd DA (2015) Party On! A call for entrepreneurship research that is more interactive, activity based, cognitively hot, compassionate, and prosocial. Journal of Business Venturing 30 (4): 489-507.

Smith JA, Flowers P and Larkin M (2009) Interpretative Phenomenological Analysis: Theory Method and Research. London: Sage.

Steier L (2009) Where Do New Firms Come From? Households, Family Capital, Ethnicity, and the Welfare Mix. Family Business Review 22 (3): 273-278.

Suurmeijer T, Doeglas DM, Briançon S, et al. (1995) The measurement of social support in the 'European research on incapacitating diseases and social support'. Social Science \& Medicine 40 (9): 1221-1229.

Swab RG, Cogan A, Pret T, et al. (2021) Examining the Creative Self-Efficacy, Goal Interdependence, and Satisfaction of New Venture Teams in the Board Game Industry. 
Entrepreneurship Research Journal. Epub ahead of print 11 October. DOI: 10.1515/erj2021-0142

Taylor SE (2011) Social Support: A Review. In: Friedman HS (ed.) The Handbook of Health Psychology. New York, NY: Oxford University Press, pp. 189-214.

Thoits PA (1982) Conceptual, methodological, and theoretical problems in studying social support as a buffer against life stress. Journal of Health and Social Behavior 23 (2): $145-159$.

Thoits PA (1995) Stress, coping, and social support processes: where are we? What next? Journal of Health and Social Behavior 35: 53-79.

Thoits PA (2011) Mechanisms Linking Social Ties and Support to Physical and Mental Health. Journal of Health and Social Behavior 52 (2): 145-161.

Treffers T, Klyver K, Nielsen MS, et al. (2019) Feel the commitment: From situational emotional information to venture goal commitment. International Small Business Journal 37 (3): 215-240.

Welter F, Baker T, Audretsch DB, et al. (2017) Everyday Entrepreneurship - A Call for Entrepreneurship Research to Embrace Entrepreneurial Diversity. Entrepreneurship Theory and Practice 41 (3): 311-321.

Wheelock J and Oughton E (1996) The Household as a Focus for Research. Journal of Economic Issues 30 (1): 143-159.

\section{Author Biographies}

Aviel Cogan is a Doctoral Candidate at the Hunter Centre for Entrepreneurship, University of Strathclyde. Her research explores social entrepreneurship, artisan entrepreneurs and the impact of identity processes on entrepreneurial practice. Her work has appeared in the International Journal of Entrepreneurial Behavior \& Research and Entrepreneurship Research Journal.

Tobias Pret is an Assistant Professor of Management and Entrepreneurship at Illinois State University. His research interests include entrepreneurship in the creative industries, social value creation and the role of context in entrepreneurial practices. His recent publications include contributions to International Small Business Journal, Entrepreneurship \& Regional Development and International Journal of Management Reviews.

Melissa S. Cardon is the Haslam Professor of Entrepreneurship and Innovation at the University of Tennessee, Knoxville. Her research focusses on the psychology of entrepreneurship, particularly how entrepreneurs as individuals and within teams can harness their passion and overcome challenges to get the best results for themselves and their organisations. She has published in a number of journals, including Academy of Management Review, Journal of Business Venturing and Entrepreneurship: Theory and Practice. 